
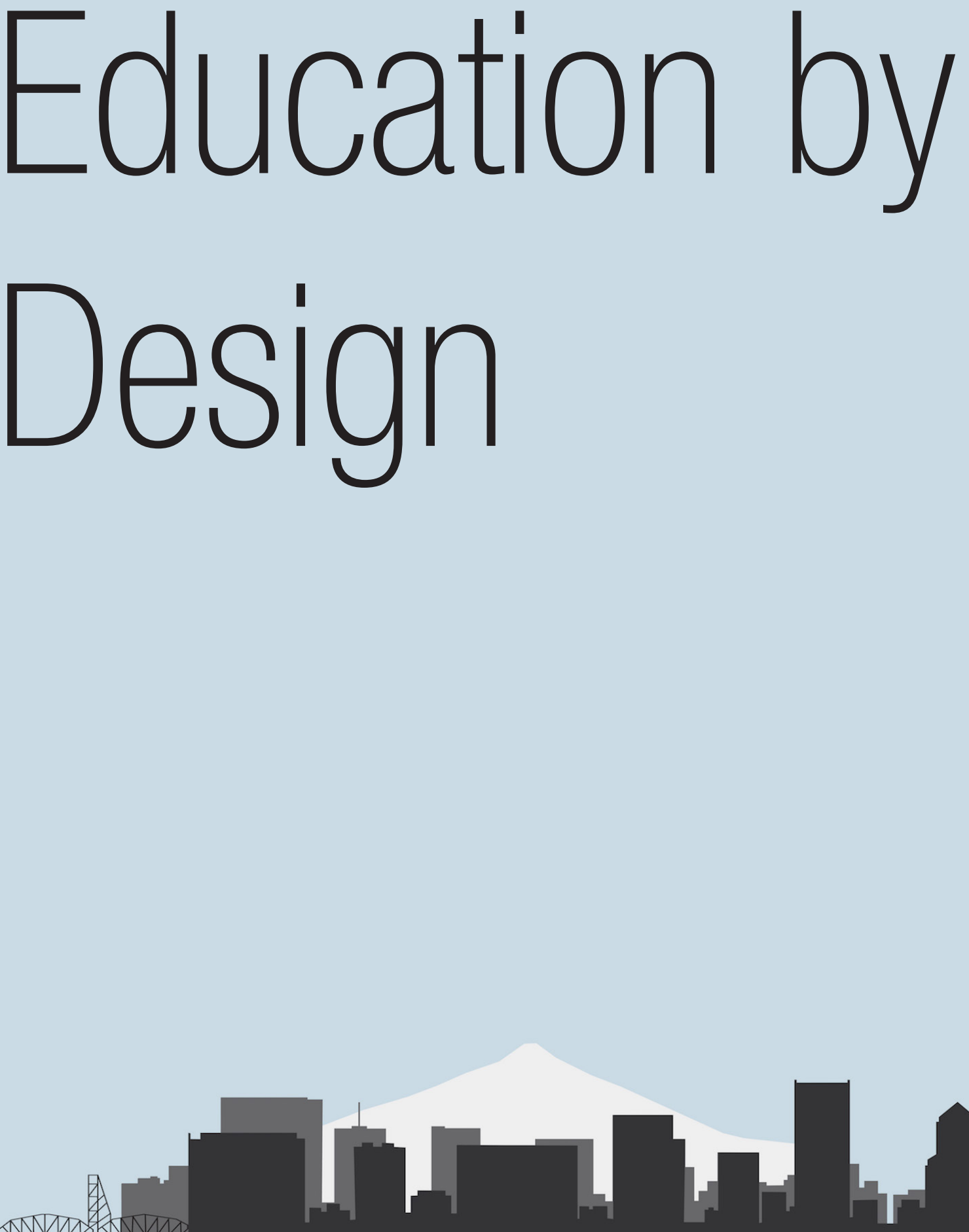

2019 Reynolds Symposium: Education by Design October 18-20, 2019 


\section{Organizing Committee:}

[co-organizers]

Professor Alison Kwok, Ph.D, FAIA, University of Oregon

Emeritus Professor John Reynolds, FAIA, University of Oregon

\section{[Symposium coordinator]}

Isabel Rivera, Ph.D., University of Oregon

Professor Walter Grondzik, P.E., Ball State University

Professor Bruce Haglund, AIA Assoc., University of Idaho

Assistant Professor Emily McGlohn, AIA, Auburn University

Associate Professor Ulrike Passe, lowa State University

Assistant Professor Siobhan Rockcastle, Ph.D., University of Oregon

Sharon Refvem, FAIA, LEED Fellow, Senior Associate and Director, Sustainability Resource Group, Hawley Peterson Snyder 


\title{
Learning from Innovative CLT Design in the United Kingdom
}

\author{
Carolina Manrique \\ Assistant Professor \\ University of Idaho \\ Moscow, ID \\ cmanrique@uidaho.edu
}

\author{
Bruce Haglund \\ Distinguished Professor \\ University of Idaho \\ Moscow, ID \\ bhaglund@uidaho.edu
}

\begin{abstract}
Cross-laminated timber (CLT) construction is an emerging technology in the Pacific Northwest (PNW). New CLT mills are being constructed in Idaho, Oregon, and Washington. We see this use of wood as a robust alternative to concrete and steel that sequesters carbon rather than spewing it into the atmosphere. Timber can be sustainably harvested in the PNW with local mills, further reducing carbon pollution in the supply chain.
\end{abstract}

In an effort to increase our Architecture Program's capacity to deliver the highest quality courses and improve student learning, we aim to equip our students with the knowledge and skills to include CLT in buildings of all scales in their design repertoire. This goal would be accomplished by extending the learning experience of the students enrolled in our study abroad program on "Green Architecture" in the United Kingdom (UK) to include research and design in the use of CLT. This new approach to focus on CLT builds upon insights and contacts made during six previous successful versions of the UK Green Architecture course (initiated in 2006).

The UK has a rich inventory of inspiring CLT projects-over 500 of which 100 are highlighted in Waugh Thistleton's 100 Projects UK CLT (2018). Our research studio during the summer of 2019 to Edinburgh and London will explore many of these inspirational buildings, engage in interviews with the architects and engineers, and participate in a design charrette in CLT-savvy London architectural firms. This unique experience will enrich the students' understanding and appreciation of mass timber construction.

\section{INTRODUCTION}

The use of wood in architecture has been a theme explored throughout undergraduate and graduate design studios at University of Idaho. Examples of this interest are our Idaho Forests Products Commission (IFPC) sponsored architectural design competition in third-year, "Timber in the City" (ACSA 2019) competitions entries in our fourth-year, and various versions (e.g. Armpriest, Haglund, Manrique) of our Integrative Architectural Design studio during the first year of our professional Master of Architecture.

Our design studio courses focused on the development of mass timber construction in the Pacific Northwest have included field trips to visit innovative buildings and offices working with recent developments in wood. An example was the visit by several advanced studios to Albina Yard (Lever Architects) "a four-story office building in Portland, Oregon, which was the first U.S. building to use a domestically made CLT structural system when it opened in September 2016. The project team chose CLT for its ability to store carbon and the smaller environmental footprint the material afforded the project." (Think Wood 2019).

Since 2006 our UK study abroad summer program has focused on providing a first-hand experience and research on cultural and urban sustainability and green buildings in the United Kingdom. The UK has been the focus of this research studio because London, and later Edinburgh added in 2013 because of the unmatched density of projects and practices that exemplify green building and urbanism. It's our sense that the UK has a decade head start on the US addressing these issues that aim to mitigate climate change. With the publication of 100 Projects UK CLT (2018) it has become apparent that lead in CLT-centric construction is also a decade ahead of the US, even in our wood construction friendly Pacific Northwest. 
There are more CLT projects in London (many with unique and innovative approaches) than in the entire US. To prepare them for full immersion in the UK's rich milieu, students participate in a spring term preparation seminar and a summer term studies abroad research studio. During the spring semester, prior to the summer experience, students "do basic research on green buildings in the UK" (Haglund 2019a). Students study the work of prominent British firms and exemplary buildings as well as green urbanism. The four-week summer term course allows them to visit architects and buildings as well as experience British culture. At the beginning of the summer term, they visit Edinburgh, Dundee, and Glasgow. After 17 days in London, the Green Serpentine Pavilion charrette is the capstone event for the course, allowing students to explore, through design inquiry, the lessons learned from their studies.

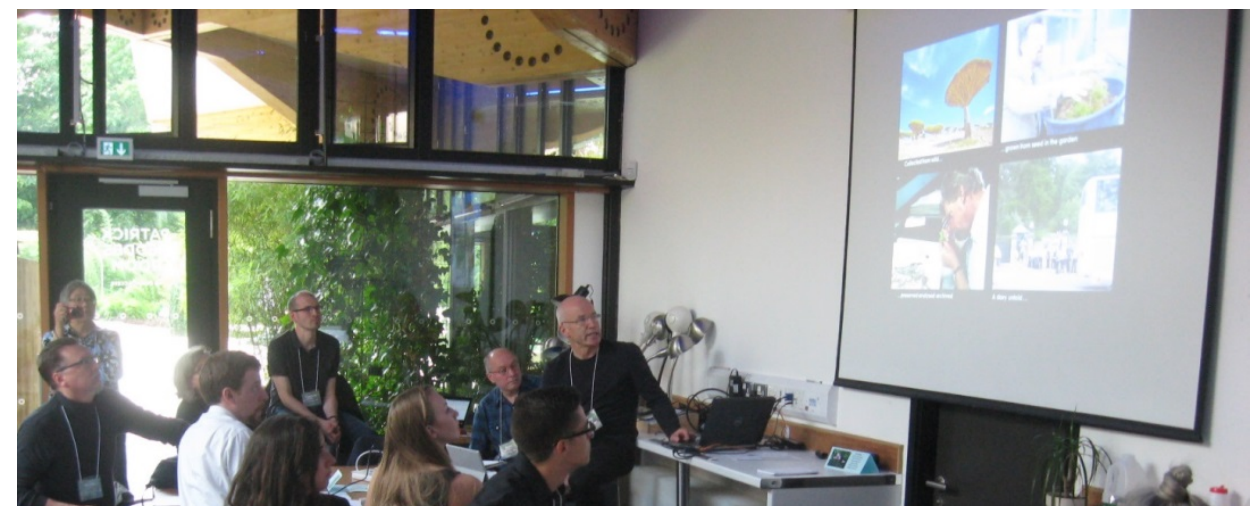

Fig. 1. Our students were at the CLT and glulam Hope Gateway learning from its architect and engineers in 2017. Roddy Langmuir, designer of the building from Cullinan Studio, presented.

Offered as an "Alternative Graduate Design Experience", ${ }^{1}$ our UK Study Abroad program this year expands the research studio model on green architecture for the first time through learning from CLT design in the United Kingdom. Encouraging a material shift through understanding and appreciation of mass timber construction has become one of our strategic approaches towards design with (a changing) climate.

The initiative of merging sustainability and wood (as a focused theme) provides opportunities to expand "exemplary lessons and activities" to inspire our students as "future stewards to shape zero net carbon buildings and communities" (University of Oregon 2019). We have organized these exemplary lessons and activities as pedagogical strategies implemented in our British Green Architecture Seminar and our UK Research Studio (see Table-1 and Table-2): expanding references, expanding activities, and applying and developing metrics (passive design).

In spring 2019, students enrolled in Arch 580 British Green Architecture Seminar "do basic research on green buildings in the UK and help plan the itinerary for the summer's studies abroad program" (Haglund 2019a). The seminar meets one-time each week (Thursdays from 5:30 to 7:00 pm) and is delivered through lectures and student presentations on assigned research and analysis topics. Students explore five topics throughout the term: Green Cities, London Orientation, Notables, Discoveries, and CLTs in the UK. Complementary activities are distributed throughout the class sessions such as English 101 and Sketching exercises. The pedagogical goal of the seminar is to form a basis for understanding and experiencing the cultural and environmental sustainability of the UK.

In summer 2019, students enrolled in Arch 552 Alternate Graduate Design Experience: UK Research (6 credits) "will visit sites; interview architects, engineers, and educators; and explore urban sustainability issues based on their first-hand experience and research. A design charrette, planned for the end of the course, will place student teams in London architectural offices for a one-day design challenge with a public presentation the following day" (Haglund 2019a). Pedagogically this is an immersive experience that aims to enhance learning.

${ }^{1}$ Arch 552 Alternative Graduate Design Experience: UK Research Studio (6 credits) 
The pedagogical strategies summarized in tables 1 and 2 proposed for our British Green Architecture Seminar (spring 2019) and our UK Study Abroad program (summer 2019) are discussed in the following two sections. These strategies in Arch 580 are aimed at providing a basis for exploring the rich inventory of green and CLT-centric buildings in the UK during the study abroad course. Tables 1 and 2 demonstrate how the strategies from Arch 580 are built upon in Arch 552.

Table 1. Pedagogical strategies in Arch 580 British Green Architecture Seminar (2 credits). Spring 2019.

\begin{tabular}{|c|c|c|c|}
\hline Strategies & Topics & Types & References \\
\hline \multirow[t]{12}{*}{ Expanding references } & \multirow[t]{3}{*}{ General } & books & (Wolfe 2016, 2019); \\
\hline & & web-links & (New Video Channel America 2019); (BBC 2019) \\
\hline & & lecture & (Wolfe 2019b) \\
\hline & \multirow[t]{3}{*}{ UK-Architecture } & books & (Allinson 2014) \\
\hline & & web-links & (Rybczynkski 2014) \\
\hline & & lecture & (Haglund 2019b) \\
\hline & \multirow[t]{5}{*}{$\begin{array}{l}\text { Green } \\
\text { buildings/cities }\end{array}$} & web-links & $\begin{array}{l}\text { (Arup 2019a); (Peters 2015); (LETI 2019); (Lopez et al. } \\
\text { 2016); (Greater London Authority 2019) }\end{array}$ \\
\hline & & web-booklets & (Arup 2014; 2016a; 2016b); (ARCADIS 2016) \\
\hline & & web-videos & (AECOM 2011) \\
\hline & & books & (Beatley 2012); (Speck 2018) \\
\hline & & Articles-other & (Haglund and Payne 2016); (Haglund 2019c) \\
\hline & CLT & Web-booklets & (Waugh Thistleton Architects 2018) \\
\hline \multirow[t]{5}{*}{ Stimulating activities } & Journaling & assignment & \\
\hline & Sketching & exercise & \\
\hline & \multirow[t]{3}{*}{ Researching } & \multirow[t]{3}{*}{ presentations } & London Orientation \\
\hline & & & Notables \\
\hline & & & CLT's in the UK \\
\hline \multirow{2}{*}{$\begin{array}{l}\text { Applying \& Developing } \\
\text { metrics (passive design) }\end{array}$} & \multirow[t]{2}{*}{ Analyzing } & \multirow{2}{*}{ presentations } & Green Cities \\
\hline & & & Discoveries workshop \\
\hline
\end{tabular}

Table 2. Pedagogical strategies in Arch 552 Alternate Graduate Design Experience: UK Research Studio (6 credits). Summer 2019.

\begin{tabular}{|c|c|c|c|}
\hline Strategies & Topics & Types & References \\
\hline \multirow[t]{11}{*}{ Expanding references } & \multirow[t]{2}{*}{ General } & Web-links & (Seeing Better Cities Group 2019); (Freud 2014) \\
\hline & & visits & \\
\hline & \multirow[t]{2}{*}{ UK-Architecture } & web-links & (The Building Centre Group Ltd. 2019); (RIBA 2019) \\
\hline & & visits & \\
\hline & \multirow[t]{2}{*}{$\begin{array}{l}\text { Green } \\
\text { buildings/cities }\end{array}$} & Web-links & $\begin{array}{l}\text { (AHMM 2019); (dRMM 2019); (Cullinan Studio 2019); } \\
\text { (Groupwork 2019); (Waugh Thistleton Architects 2019) }\end{array}$ \\
\hline & & visits & \\
\hline & \multirow[t]{3}{*}{ Timber Construction } & web-links & (Think Wood 2019); (WoodWorks 2019); (TRADA 2019) \\
\hline & & web-booklets & (Arup 2019b) \\
\hline & & visits & \\
\hline & \multirow[t]{2}{*}{ CLT } & web-booklets & $\begin{array}{l}\text { (Waugh Thistleton Architects 2018); (Structurlam Mass } \\
\text { Timber Corporation 2018; 2019); (FPInnovations and } \\
\text { Binational Softwood Lumber Council 2013) }\end{array}$ \\
\hline & & visits & \\
\hline \multirow[t]{4}{*}{ Stimulating activities } & Journaling & assignment & \\
\hline & Sketching & assignment & \\
\hline & Building & Project & Construction project (timber) in Suffolk \\
\hline & Designing & Charrette & Serpentine Pavilion; Green Building; CLT \\
\hline \multirow{2}{*}{$\begin{array}{l}\text { Applying \& Developing } \\
\text { metrics (passive design) }\end{array}$} & Analyzing & assignment & Discoveries \\
\hline & Designing & Charrette & $\begin{array}{l}\text { Serpentine Pavilion; Green Building; CLT. (SBSE 1999; } \\
\text { 2009) }\end{array}$ \\
\hline
\end{tabular}




\section{BRITISH GREEN ARCHITECTURE SEMINAR (SPRING 2019)}

During spring 2019, the Arch 580 British Green Architecture Seminar builds the base of references and skills students will apply on site visits and discovery exercises during the summer research studio.

\section{Expanding References}

The seminar starts with an introductory overview of the UK Study Abroad Program providing the general structure of what the experience has been in previous years and what is planned for summer 2019 .

\section{General, UK-Architecture, Green Buildings/Cities and CLT}

Through assigned readings and applied research assignments, references are introduced. Chuck Wolfe's (2016, 2019a) readings on Seeing the Better City aim to provide students with guidelines to document their personal experience through text and photographs. The readings were supplemented by a live webinar by the author. Allinson and Thornton's (2014) London's Contemporary Architecture serves as an "explorer's guide" for navigating London and identifying sites of interest.

In order to expand the green building approach in the UK Study Abroad program, the preparation seminar introduced Waugh Thistleton's (2018) book, which highlights 100 inspiring CLT projects selected from over 500 in the UK.

English 101 exercises, at the beginning of some class sessions, aim to familiarize students with terms and expressions particular to the UK's English language usage, and other aspects of the British culture. Students are encouraged to read about, watch, and listen to examples categorized as "mind the gap" (in New Video Channel America and BBC).

\section{Stimulating Activities}

\section{Journaling and Sketching}

Students are required to keep a critical journal of the seminar activities in spring in preparation for the thorough record and analysis assigned while studying abroad during the summer term.

Sketching exercises (10 minutes at the beginning of most class sessions) are aimed to stimulate building drawing skills for use during the visits during the summer research studio.

\section{Researching (London Orientation)}

Based on Allinson and Thornton's London's Contemporary Architecture: An Explorer's Guide (2014), each student was assigned a specific neighborhood in central London. Their task was to plan a walk through the assigned area, citing buildings and environments of interest and planning logistics before, during, and after the walk. The intent of this exercise is two-fold, gaining knowledge of the architectural richness of the city and appreciation of the robust transit system that allows green transportation via tube, bus, bicycle, and walking.

\section{Researching (Notables and CLTs in the UK)}

Students were assigned a notable architect or building to present to the class. Content required included: architect's or building's name and photo; educational background and work history for architects, construction date for buildings; design philosophy/ design intent; important green building strategies (a caption and photo of each); references; office or building location map and transportation options. The assigned notable architects or buildings were: ZHA; dRMM; RSH; Herzog \& De Meuron; John Soane; Mackintosh \& McDonald; AHMM; Waugh Thistleton; Vitsoe \& US Embassy; Allies \& Morrison; Arup; Scottish Parliament; Victoria and Albert Museum in Dundee; Cullinan Studio; Norman Foster.

For researching CLT in the UK students were assigned a building to present in class. Most of the assigned buildings are presented as a two-page case study in CLT 10o UK Projects (Waugh Thistleton Architects 2018) and "have been categorized as 'Pure CLT' (CLT alone), 'Pure Timber' (CLT combined with other timber elements such as glulam), or 'Hybrid' (CLT combined with other structural materials such as steel 
or concrete)" (Waugh Thistleton Architects 2018, 99). This multiplicity of CLT strategies demonstrates a richness of approach not yet attained in the PNW.

- Education: Open Academy Norwich (p. 115), Arcadia Nursery (p. 139), Essex University Business School (p. 153), St. Clare's College Art Studio (p. 215).

- Residential: Barrett's Grove (p. 207).

- Commercial: Alex Monroe Studio (p. 243); Sky Believe in Better Building (p. 247).

- Public \& Civic: Lumen Reform Church (p. 271); The Garden Museum (p. 273); Regent's Park Open Air Theatre (p. 289); Olympic Park Timber Lodge (p. 295); Maggie's Centre, Wilkinson Eyre, Oxford (p. 299); The Gateway Buildings (p. 309).

Students were required to expand, interpret, and analyze information from the text and corroborating sources as well as provide color images of and graphics about the project that explain the use and significance of CLTs. In order to familiarize students with the case studies in context, student presentations included one slide showing how to get to the project from their dormitory in Edinburgh or London with a map (using online sources such as Google.com, openstreetmap.org, and national or local transportation websites). ${ }^{2}$ Similar to the previous discoveries assignments, students reported on how long would it take and how much it would cost to get to each location.

\section{Applying and Developing Metrics (Passive Design)}

Analyzing (Green Cities and Discoveries)

Using the Green Cities Checklist provided to guide the analysis, students (in pairs) were required to present comparative analysis of two assigned cities. Each team was assigned a city presented in the textbook, Green Cities of Europe (GCE) (Beatley 2012), and a North American city with which to compare it. Students were required to distill, interpret, and analyze information from the text and corroborating sources that support or argue against the author's claims and the "National Geographic rating" (if rated) (Lopez et al. 2016). The following paired cities were assigned: Paris \& Portland; Freiburg \& Seattle; Vitoria-Gastiez \& Vancouver; Helsinki \& Boston; Venice \& Moscow, ID; Copenhagen \& New York; London \& Edinburgh. Our intent is to engender awareness of how cities address green issues on multiple scales that are broader than simply examining green buildings.

Two assignments were required as part of the Discoveries Workshop series (1 \& 2). For the Discoveries Workshop-1 students were assigned a London Discovery Experience as listed in Table-3 to present to the class based on research and analysis using the corresponding Green Cities Scorecard (GCS) provided, plus at least one other. For example, the GCS for Culture - Daylighted Museums defines the following components for rating ( 1 through 5 ): free museum access, pedestrian friendly, local food venues, transit connection, and diverse cultural offerings. Students were required to discuss what to look for that contributes to London's green urbanism. During the research studio in summer, students will be required to visit, record, analyze, and critique (through dialogue, sketches, still photography, words, and diagrams) at least four discovery experiences.

The reading assignments for this exercise were based on two references: Seeing the Better City (Wolfe 2016) and Walkable City Rules: 101 Steps to Making Better Places (Speck 2018). From Seeing the Better City (Wolfe 2016), students were assigned to read Chapter-3 "Seeing the City through Urban Diaries" (p. 59-88). This chapter summarizes traditional approaches of chronicling urban change made by observers, noting the ways cities evolve (written or visual historical descriptions), and "provides hints about taking better photographs and using them in urban diaries" (Wolfe 2016, 59). From Walkable City Rules (Speck 2018) students were assigned to refer their discoveries to selected rules in order to focus on specifics of pedestrian-friendly urban environments.

${ }^{2}$ Recommended online transportation resources include https://transportforedinburgh.com/ for Edinburgh, https://tfl.gov.uk/ for London, and https://www.nationalrail.co.uk/ for other routes. 
Table 3. Discoveries in London assigned, and building and sites selected by students

\begin{tabular}{|l|l|}
\hline $\begin{array}{l}\text { Discovery/Green Cities } \\
\text { Scorecard }\end{array}$ & Buildings and Sites \\
\hline $\begin{array}{l}\text { 1-CLT's in the UK- } \\
\text { Energy/Carbon }\end{array}$ & See “100 Projects UK CLT" (Waugh Thistleton Architects 2018) \\
\hline $\begin{array}{l}\text { 2-Shading Tall Buildings- } \\
\text { Energy/Carbon }\end{array}$ & $\begin{array}{l}\text { See (Allinson \& Thornton 2014). The Shard; Heron Tower; 30 St. Mary Axe, The Gherkin; } \\
\text { The Leadenhall Building; Bloomberg's European HQ; US Embassy }\end{array}$ \\
\hline 3-Public Squares-Biophilia & Russell Square (James Burton); Berkeley Square (William Kent); Grosvenor Square \\
\hline $\begin{array}{l}\text { 4-South Bank of the Thames- } \\
\text { Walkability }\end{array}$ & $\begin{array}{l}\text { Westminster Bridge; London Eye; Hungerford Bridge; Royal Festival Hall; National Theatre; } \\
\text { Tate Modern; Millennium Bridge; Shakespeare's Global Theatre; London City Hall; Tower } \\
\text { Bridge }\end{array}$ \\
\hline 5-Daylighted Museums-Culture & $\begin{array}{l}\text { British Museum; Design Museum; National Gallery; Natural History Museum; Science } \\
\text { Museum; Tate Modern; Victoria \& Albert Museum }\end{array}$ \\
\hline 6-City Markets-Metabolism & $\begin{array}{l}\text { Borough Market; Leadenhall Market; Smithfield Market; Covent Garden; Camden Market. } \\
\text { Other markets in the UK: Edinburgh's Farmers Market; Oxford's Covered Market. }\end{array}$ \\
\hline 7-Pedestrian Zones-Walkability & Carnaby Street; Shepherd's Market; South Moulton Street; St. Christopher's Place \\
\hline 8-Rail Connectivity-Mobility & $\begin{array}{l}\text { Train stations: King's Cross; St. Pancras International; Euston; Marylebone; Paddington; } \\
\text { Victoria; Charring Cross; Waterloo; Liverpool Street. }\end{array}$ \\
\hline 9-Self-Defined-Your Choice & Choose a topic, pertinent site(s), and at least two pages from the GCS for the experience. \\
\hline
\end{tabular}

For the Discoveries workshop-2, Chuck Wolfe, author of Seeing the Better City (2016) and Urbanism without Effort: Reconnecting with First Principles of the City (2019), delivered a live videoconference to the class. Students were required to prepare a $24 \times 36$ black and white poster of their assigned discovery. On these posters, students made notes based on their readings, previous week's presentation and Chuck Wolfe's presentation. Our aim is to refine their sensitivity to green urbanism in preparation for a scheduled walking workshop with Chuck Wolfe in London.

\section{ALTERNATE GRADUATE DESIGN EXPERIENCE: UK RESEARCH STUDIO (SUMMER 2019)}

In summer 2019, Arch 552 Alternate Graduate Design Experience: UK Research Studio is developed through a hands-on immersion experience of one month (June $25^{\text {th }}$ to July $22^{\text {nd }}$ ). Pedagogical strategies implemented during this term aim to build on references introduced during the seminar, stimulate opportunities to develop journaling and sketching skills during the visit of selected buildings and sites, and engage in hands-on building and designing experiences. Students also are required to apply and develop metrics (passive design) in their selected discoveries and assigned design charrette.

\section{Expanding References}

In addition to the resources assigned and used for research and analysis exercises during the preparation seminar in spring, the research studio in the UK expands references based on online availability (weblinks) and experiential activities (visits). To stimulate students for the adventure ahead, additional readings between the spring and summer courses were recommended, for example Freud's Mr. Mac and $M e$ (2014) on the architect Charles Rennie Mackintosh (1868-1928) protagonist of programmed visits in Glasgow, Dundee, and Suffolk.

General, UK-Architecture \& Green Buildings/Cities

In order to follow updates from Chuck Wolf, his online resources through Seeing Better Cities Group (2019) were recommended. A guided walking tour is programmed with Chuck Wolfe in King's Cross (London) and Richmond. A variety of online resources on the Built Environment are available through the website of The Building Centre Group Ltd (2019) including exhibits, presentations, courses (e.g. townscape sketching), a product directory for specifying projects, and updates on latest and greatest building projects. The RIBA (2019) website provides a variety of resources on architecture, architectural firms, events (e.g. exhibits, lectures, festivals, etc.) and awards and competitions such as the prestigious RIBA Stirling Prize. Visits are programmed to exemplar UK architecture buildings and sites that feature green buildings and urbanism, cultural sustainability, and use of local transit. 
Visits programmed in Edinburgh include: Bayes Centre at the University of Edinburgh (Bennetts Associates 2018) winner of the 'Large Project' Award at the 2019 Edinburgh Architectural Association Awards (Bennetts Associates 2019; The University of Edinburgh 2019); Royal Botanic Gardens Edinburgh's John Hope Gateway (Cullinan Studio 2009), Scottish Parliament (Enric Miralles 1999-2004) the Stirling Prize winner in 2005; Dynamic Earth (Michael Hopkins). Other recommended sites are the Edinburgh Castle, the National Museum of Scotland, the National Portrait Gallery, and Arthur's Seat.

Visits programmed in London include: St. Paul's Cathedral; Victoria and Albert Museum; Serpentine Pavilion and Gallery, and Serpentine Sackler Gallery; Bloomberg Building (Norman Foster 2018 Stirling Prize); UCL Bartlett Summer Show at the School of Architecture and Here East facility; Building Centre; Architecture Association; British Museum; Sir John Soane's Museum; Laban Dance Centre (Herzog \& de Meuron Stirling Prize 2003); Painted Hall; Thames Barrier; The Crystal (Wilkinson Eyre, closed for remodel) "one of the world's most sustainable buildings, achieving Outstanding BREEAM accreditation and Platinum LEED accreditation" (Siemens plc 2016); Lily Jencks Studio's pop-up garden installation ("The Quintessential English Garden: what does it mean to be local?"); BedZED "the UK's first large-scale eco-village" (Bioregional 1997-2002), Housing Design Award for sustainability from the Royal Institute of British Architects in 2001 and was shortlisted for the Stirling Prize in 2003 (Bioregional 2019); and Kew Gardens.

Other experiential activities programmed include climbing the dome of St. Paul's Cathedral, attending "A Midsummer Night's Dream" at the Shakespeare's Globe Theatre, and viewing the city from the London Eye.

Visits programmed in other cities include: The Lighthouse and the House for an Art Lover (Charles Rennie Mackintosh), and the Glasgow School of Art in Glasgow; Victoria \& Albert Museum (Kengo Kuma 2007-2018), McManus Gallery and Dundee Contemporary Arts in Dundee; Oxford Eco-House, Keble College, St. Clare's College Art Studio, and Oxford University Museum of Natural History in Oxford.

\section{Timber Construction - CLT}

In addition to Waugh Thistleton Architects (2018) 10o Projects UK CLT used during the spring term and available through the Think Wood (2019) website, some of the resources recommended are available as online resources in WoodWorks (2019), Structurlam Mass Timber Corporation (2019) and TRADATimber Research And Development Association (2019). Some recommended resources include the CLT Handbook US Edition (FPInnovations and Binational Softwood Lumber Council 2013) and the CrosslamCLT US Technical Design Guide (Structurlam Mass Timber Corporation 2018).

Expanding references for learning from wood and innovative CLT Design during the research studio in the United Kingdom focuses on organized visits to buildings and architecture offices working with this material. Visits organized to explore CLT buildings in the UK include: The John Hope Gateway (Cullinan Studio 2009) at the Royal Botanic Garden in Edinburgh; St. Clare's College Art Studio in Oxford; ARIA 168 Upper Street (Groupwork 2018), Stadthaus/Murray Grove (Waugh Thistleton 2009) and the Olympic Park Timber Lodge (Erect Architects 2013) in London. Visits to other buildings using wood in London include: the Dulwich Pavilion 2019 (The Colour Palace 2019 by Pricegore architects and designer Yinka Llori); and the Crossrail Place Roof Garden Canary Wharf (Foster + Partners 2019) a diagrid vault of glulam and fritted ETFE glazing.

\section{Stimulating Activities}

Journaling, Sketching, Building and Designing will constitute the hands-on activities to be developed for a full immersion experience during the summer research studio in the UK.

\section{Journaling}

While studying abroad, students are required to keep a critical journal of their experiences focusing on both sustainable architecture and green urbanism-in their three dimensions environmental, cultural, and economic. Evaluation of the city's components vis-à-vis the appropriate Green City Scorecards and urban diary keeping would be appropriate and useful. The journal is required to include: a calendar 
(itinerary, sites visited and events attended); documentation and analysis of four discovery experiences; Critical analysis of (green) buildings visited (architects identified, commentary, sketches, diagrams, and photographs); Review of the (architecture) office visits and body of work presented with comments, sketches, and photographs; Critical presentation of the process and results of the charrette; Reviews and analyses of visits to cultural sites (e.g. museums, parks, theatres, and educational facilities); Experience and analysis of multiple modes of transportation. Critical review of each conference, lecture, and debate presentation (illustrating as appropriate).

\section{Sketching}

Most visits are scheduled requiring students to arrive at the site at least thirty-minutes before in order to allow for sketching sessions. A compilation of sketches from programmed visits, independent discovery sessions, and design process during the charrette are required as part of the journal submissions.

\section{Building}

Students will participate in a two-day construction project in the Suffolk countryside. In 2017 students helped build a heavy timber frame from a kit-of-parts (see figure-2).
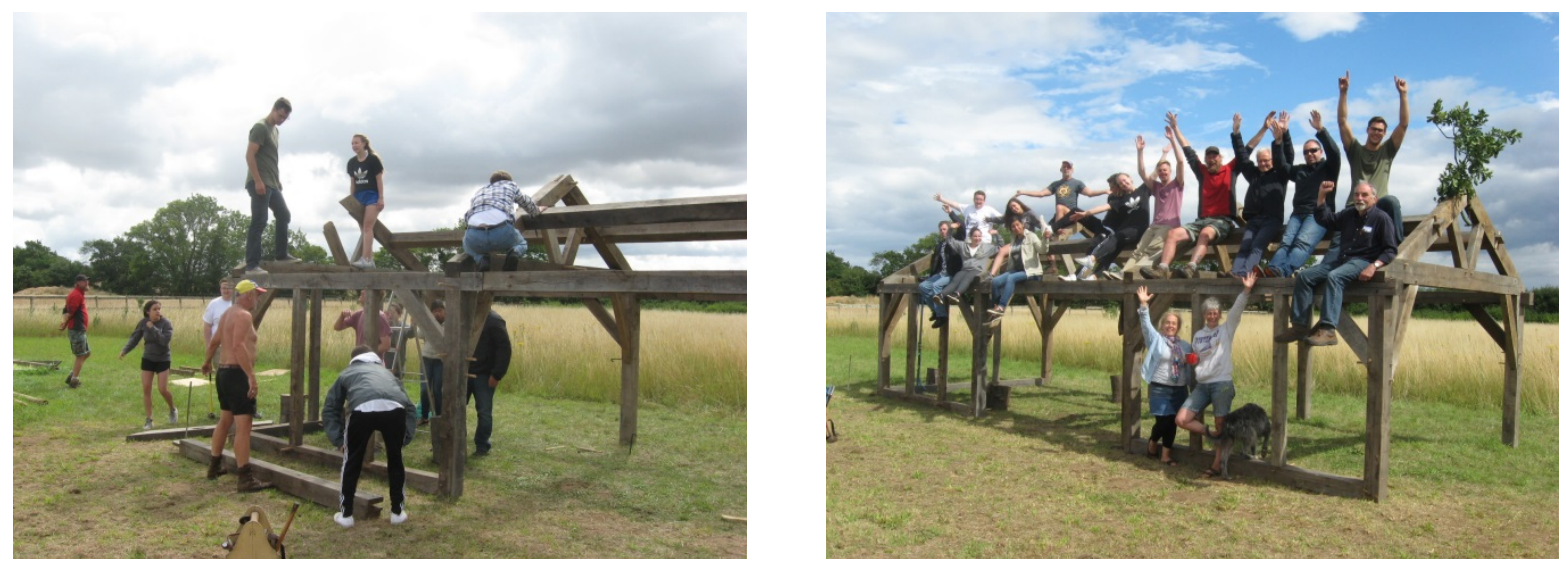

Fig. 2. Students constructing a heavy timber frame in Suffolk, UK (2017)

\section{Designing (Charrette - The Green Serpentine Pavilion)}

The Serpentine Gallery Pavilion commission was conceived by Serpentine Gallery Director, Julia PeytonJones, in 2000. It is an ongoing programme of temporary structures by internationally acclaimed architects and designers. It is unique worldwide and presents the work of an international architect or design team who, at the time of the Serpentine Gallery's invitation, had not completed a building in England. Each Pavilion is sited on the Gallery's lawn for three months or more and the immediacy of the process - a maximum of six months from invitation to completion-provides a peerless model for commissioning architecture. Zaha Hadid also remodeled the 1805 gunpowder storehouse into the new Serpentine Sackler and Magazine Cafe just across the Serpentine Bridge to the north of the Serpentine Gallery and Pavilion.

The Design Charrette “The Green Serpentine Pavilion,” planned for our research studio in London (summer 2019), challenges our architecture graduate students to design an alternative Serpentine Pavilion that serves as an exemplar of design ideas crucial to mitigating the specter of global climate change. The pavilion, as an annual celebration of fine architecture, will endeavor to educate the public as well as the design community about pressing architectural issues. This year's focus, expanding our green building approach in the five previous iterations, is on using CLT's as the primary structural material.

On the day of the charrette (scheduled for 17 July 2019, all day) three four-person teams of students will work in CLT-savvy London architectural firms (The three architectural firms in London selected this year are Waugh Thistleton Architects, Cullinan Studio, and Groupwork, all experienced advocates of CLT construction) with a member or two of the firm acting as host/mentor. Students present their design 
proposals on 18 July. Design firm hosts/mentors are welcome to join in the presentations as onlookers, presenters, and/or as critics.

Waugh Thistleton Architects (2019) has experience in delivering a wide range of building types (residential, commercial, mixed-use and cultural) and has gained international reputation in environmentally sustainable architecture and design through their commitment to the use of timber construction. In 2003 they built their first CLT building, which began a series of significant timber structures. In 2017 this firm built "the first building in the UK to be made entirely of LVL" for the new Vitsoe Headquarters (Waugh Thistleton Architects 2018, 261). Other examples include: Curtain Place (2015), "a hybrid CLT and steel structure" in London (Waugh Thistleton Architects 2018, 253), Dalston Works (2017) in London, "the world's largest CLT building" with 121 new affordable and private (for rent) homes, 38,000 sqft of commercial space, and 10 storeys at its highest point (Waugh Thistleton Architects 2018, 229); The Stadthaus/Murray Grove (2009) Pure CLT 9-storeys residential project in London, "first tall building using engineered timber, and was the tallest timber residential structure in the world at the time of completion" (Waugh Thistleton Architects 2018, 179).

Cullinan Studio (2019) are the designers of the John Hope Gateway (2009) at the west entrance to the Royal Botanic Garden Edinburgh was the first project using "CLT for a public building in Scotland" (Waugh Thistleton Architects 2018, 275). In addition to the development of buildings and masterplans, this architectural firm is actively involved in consultant collaborations with organizations such as TRADA (2019) to promote engineered timber solutions for buildings.

Groupwork (2019), formerly Amin Taha Architects, are the designers of Barretts Grove (2016), shortlisted for the RIBA Stirling Prize in 2017, a six-story residential project in Pure CLT with exposed loadbearing structural walls and roof panels (Waugh Thistleton Architects 2018, 207) and 168 Upper Street (2018), concrete-formed exterior bearing wall with CLT floor plates and partition walls. Amin Taha Architects and Groupwork's 15 Clerkenwell Close received a RIBA National Award in 2018.

\section{Applying and Developing Metrics (Passive Design)}

\section{Analyzing (Discoveries)}

In addition to the proposed Discoveries developed for the Workshop series (1 \& 2) during the preparation seminar in spring 2019, other themes for on-site analysis are encouraged such as Historic Fabric/Adaptive Reuse (Rule-91: Save Those Buildings in Speck 2018, 216).

\section{Designing (Charrette - Green Serpentine Pavilion)}

Corroborated by the opinion piece, "It's time for a new Brief at London's Serpentine" (Building Science 05/18/2012), which calls for asking a different group of students each year (instead of star-architects) to design and build the Serpentine Gallery taking into account "criteria about the provenance of materials, sustainability, and reuse," our students have been required to propose designs for the alternative Serpentine Pavilion answering the challenge of Carbon-Neutral Design every other year since 2009.

The teams' design proposals should, in addition to addressing the spirit of the Serpentine Gallery Pavilion Commission, be beautiful, environmentally responsible, and culturally relevant - an educational experience. The design should address the issues of green (carbon-neutral, zero net energy) architecture including passive heating and cooling, active hot-water and electricity generation, green construction materials and methods, reduced energy use, low-carbon cafe menu, public education on green architecture, water use and supply, transportation, species equity, demountable design, future use(s), and solid waste management. The Regeneration-Based Checklist for Design and Construction (SBSE 1999) is used to help evaluate design proposals holistically. An updated version of the checklist addresses carbon considerations (SBSE 2009). 


\section{CONCLUSIONS}

Cross-laminated timber (CLT) construction emerging in the Pacific Northwest provides an exciting opportunity for developing pedagogical initiatives that enhance our students' knowledge and skills in in increasing the use of timber architectural design. We recognize the development of timber construction as an opportunity to increase our Architecture Program's commitment to environmentally sustainable architecture education. The use of CLT reinforces a much needed (material) shift in designing within a rapid change in climate.

Our study abroad program in the United Kingdom, offered since 2006 with a focus on Green Architecture, is expanding content and pedagogical strategies to include CLT in this immersive experience. The UK provides a stimulating context for our students to explore inspirational CLT buildings in Edinburgh, Oxford, and London, and engage in interviews with architects and engineers from CLT-savvy London architectural firms through programmed visits and participation in the design charrette.

The summer research studio (Arch 552 Alternate Graduate Design Experience, summer 2019) and its preparation seminar (Arch 580 British Green Architecture Seminar, spring 2019), offered as a required sequence of courses, are developed to enrich students' understanding and appreciation of mass timber construction as a green building approach in architectural design within the contexts of culture, climate, and environment. Content and pedagogical strategies implemented include expanding references (UK Architecture, Green Building/Cities and CLT), stimulating activities (Journaling, Sketching, Researching, Analyzing and Designing), and applying and developing (passive design) metrics in analysis and design assignments. Overall results of the summer experience in the UK (25 June to 22 July 2019) will be reported at the Reynolds Symposium in fall 2019.

This year's course has been built on the sequence of six successful iterations. After his experience with the students in London Chuck Wolfe commented on Linked-In, "So impressed by your class organization and how you have built it up over the years, Bruce. Really a stellar example for others who are attempting similar feats.”

\section{REFERENCES}

Association of Collegiate Schools of Architecture (ACSA). 2019. "Timber in the City: Urban Habitat Competition”. Accessed June 18, 2019. https://www.acsa-arch.org/programsevents/competitions/2018-2019-timber-in-the-city

AECOM Global Cities Institute. 2011. "Global Cities”. From August 9, 2011 in Vimeo. Accessed June 3 2019. https://vimeo.com/27484133

AHMM. 2019. “Allford Hall Monaghan Morris: Awards. Accessed June 18, 2019. https://ahmm.co.uk/Awards/

Allinson, Kenneth. Thornton, Victoria. 2014. London's Contemporary Architecture: An Explorer's Guide. 6th edition, Architectural Press.

ARCADIS. 2016. "Sustainable Cities Index 2016: Putting people at the heart of city sustainability". Accessed June 3 2019. https://www.arcadis.com/media/o/6/6/\%7Bo6687980-3179-47AD-89FDF6AFA76EBB73\%7DSustainable\%20Cities\%20Index\%202016\%20Global\%20Web.pdf

Arup. 2014. “Cities Alive: Rethinking Green Infrastructure”. Accessed May 29, 2019. https://www.arup.com/perspectives/publications/research/section/cities-alive-rethinking-greeninfrastructure

Arup. 2016a. "Cities Alive: Green Building Envelope”. Accessed May 29, 2019. https://www.arup.com/perspectives/publications/research/section/cities-alive-green-buildingenvelope 
Arup. 2016b. “Cities Alive: Towards a Walking World”. Accessed May 29, 2019.

https://www.arup.com/perspectives/publications/research/section/cities-alive-towards-a-walkingworld

Arup. 2019a. "Cities Alive". Accessed May 29, 2019. https://www.arup.com/perspectives/cities-alive

Arup, 2019b. "Rethinking Timber Buildings”. Accessed May 29, 2019. https://www.arup.com/perspectives/publications/research/section/rethinking-timber-buildings

Beatley, Timothy. 2012. Green Cities of Europe: Global Lessons on Green Urbanism. Island Press.

Bioregional. 2019. "BedZED - the UK's first large-scale eco-village”. Accessed June 18, 2019. https://www.bioregional.com/projects-and-services/case-studies/bedzed-the-uks-first-large-scaleeco-village

Cullinan Studio Ltd. 2019. “Cullinan Studio”. Accessed June 18, 2019. http://cullinanstudio.com/

Foster + Partners. 2019. "Crossrail Place Canary Wharf (2015-London, UK)”. Accessed June 17, 2019. https://www.fosterandpartners.com/projects/crossrail-place-canary-wharf/

FPInnovations and Binational Softwood Lumber Council. 2013. "CLT Handbook US Edition”. From Think Wood. Accessed June 11, 2019. https://info.thinkwood.com/clt-handbook

Freud, Esther. 2014. Mr. Mac and Me. Bloomsbury.

Greater London Authority. 2019. “Environment”. Accessed June 32019. https://www.london.gov.uk/what-we-do/environment

Groupwork. 2019. “Groupwork”. Accessed June 18, 2019. http://groupwork.uk.com/

Haglund, Bruce. 2019a. “Arch 580 English Green Building Seminar, Spring 2019”. Accessed May 29, 2019. https://www.webpages.uidaho.edu/arch504ukgreenarch/default.htm

Haglund, Bruce. 2019b. “Temporary Pavilions: Serpentine Pavilion-Presentation” Accessed June 3, 2019. https://www.webpages.uidaho.edu/arch504ukgreenarch/Serpentine.pdf

Haglund, Bruce. 2019c. "Green City Checklist”. Accessed June 3, 2019. https://www.webpages.uidaho.edu/arch504ukgreenarch/greencitieschecklist-te.pdf

Haglund, Bruce. Payne, Malachi. "A Green Cities Checklist: A Subjective Rating Rubric”. Presented at PLEA2016 Cities, Buildings, People: Towards Regenerative Environments. Los Angeles, United States. July 11-13, 2016.

LETI - London Energy Transformation Initiative. 2019. "LETI Declaration”. Accessed May 29, 2019. https://www.leti.london/declaration

Lopez, Albert L. Santamarina, Daniela. Nowakowski, Kelsey. 2016. “The World's Top Cities for People and the Planet" in National Geographic: Urban Expeditions. Accessed June 32019. https://www.nationalgeographic.com/environment/urban-expeditions/green-buildings/sustainablecities-graphic-urban-expeditions/

Peters, Adele. 2015. "7 Cities that are starting to go Car-Free". From January 13, 2015. Accessed May 29 2019. https://www.fastcompany.com/3040634/7-cities-that-are-starting-to-go-car-free

RIBA. 2019. “RIBA - Royal Institute of British Architects”. Accessed June 18, 2019. https://www.architecture.com/about 
Rybczynkski, Witold. 2014. "Ian Ritchie's New Memoir Explores How a Generation of British Architects Engineered Their Rise". From August 27, 2014 in Architect: The Journal of the AIA. Accessed May 29, 2019. https://www.architectmagazine.com/practice/ian-ritchies-new-memoir-explores-how-ageneration-of-british-architects-engineered-their-rise 0

SBSE. 1999. "Regeneration-Based Checklist for Design and Construction”. From January 2, 2018. Accessed June 11, 2019. https://www.sbse.org/resources/regeneration-based-checklist-design-andconstruction

SBSE. 2009. "Regeneration-Based Checklist for Carbon-Neutral, Zero Net Energy Design and Construction”. From January 1, 2018. Accessed June 11, 2019. https://www.sbse.org/resources/updated-version-carbon-considerations

Seeing Better Cities Group. 2019. "Improve you City through Critical Observation”. Accessed June 11 2019. http://seeingbettercities.com/

Siemens plc. 2016. “The Crystal: A Sustainable Cities Initiative by Siemens”. Accessed June 17, 2019. https://www.thecrystal.org/about/

Speck, Jeff. 2018. Walkable City Rules: 101 Steps to Making Better Places. Island Press.

Structurlam Mass Timber Corporation, 2018. "Crosslam CLT Technical Design Guide”. Accessed June 6, 2019. https://www.structurlam.com/wp-content/uploads/2016/10/US-Design-Guide-2018.pdf

The Building Centre Group Ltd. 2019. “The Building Centre”. Accessed June 11, 2019. https://www.buildingcentre.co.uk/

The University of Edinburgh. 2019. "Bayes Centre”. Accessed June 17, 2019. https://www.ed.ac.uk/bayes/about-us/our-building

Think Wood. 2019. "Cross-Laminated Timber (CLT)" in Think Wood. Accessed June 11, 2019. https://www.thinkwood.com/products-and-systems/mass-timber/cross-laminated-timber-clt$\underline{\text { handbook }}$

TRADA- Timber Research and Development Association. 2019. "TRADA: The Leading Authority on Wood”. Accessed June 18, 2019. https://www.trada.co.uk/

University of Oregon. n.d. “2019 Reynolds Symposium: Education by Design” Accessed May 14, 2019. https://reynoldssymposium.uoregon.edu/call-for-submissions/

Waugh Thistleton Architects. 2018. 100 Projects UK CLT. Accessed May 29, 2019. https://info.thinkwood.com/100-uk-clt-projects

Waugh Thistleton Architects. 2019. Waugh Thistleton Architects. Accessed June 6, 2019. http://waughthistleton.com/practice/\#showabout

Wolfe, Charles R. 2016. Seeing the Better City: How to Explore, Observe and Improve Urban Space. Island Press.

Wolfe, Charles R. 2019a. Urbanism without Effort: Reconnecting with First Principles of the City. Island Press.

WoodWorks, 2019. "Mass Timber/Resources" in WoodWorks: Wood Products Council. Accessed June 6, 2019. https://www.woodworks.org/design-and-tools/building-systems/mass-timberclt-code-related/ 